\title{
COMPLEXITIES IN DEALING WITH GENDER INEQUALITY Muslim Women and Mosque-Based Social Services in East Java Indonesia
}

\author{
Mufidah Ch \\ UIN Maulana Malik Ibrahim Malang | fidah_cholil@syariah.uin-malang.ac.id
}

\begin{abstract}
This paper applies an Islamic legal sociology approach to criticize the typology of East Java society and their views on gender equality, women's empowerment, and women's roles in mosques based on the subcultures of East Java community: Mataraman, Tapal kuda, and Arek'an. The concept of male-female equality has not been fully accepted by religious leaders. There is a power relation in the Muslim society's high-power structure because religious leaders are still dominated by men while women are considered as subordinate and marginal groups. On the one hand, there is still a patriarchal cultural-based political configuration that affects gender discrimination. On the other hand, the Muslim community has not been completely established to protect women. Finally, the finding of this paper is that the role of mosque-based women in three sub-cultures of East Java shows different results. The subculture of Mataraman tends to be culturebased, whereas religion is considered as a supporting factor. The subculture of Tapal Kuda prefers to collaborate religious views with patriarchal cultures. Finally, the subculture of Arek'an is likely to dialogue religion with culture more inclusively. A progressive mosque that provides women's empowerment may break the chain of the gender-biased understanding and change the mindsets of patriarchal Muslim societies through dialogue, social interaction, and productive activities.
\end{abstract}

Keywords: Muslim society, mosque, gender equality.

\section{Introduction}

The discourse of gender equality has been a controversial issue. Some parties in the community feel worried and suspicious. Different 
factors contribute to their concern on gender equality. First, the interest to maintain the status quo as part of patriarchal cultural manifestations; Second, there is still a strong textual understanding; Third, the rejection of Western culture as a modern jäbiliyya (age of ignorance) that carries the issue of gender equality in Muslim societies. On the other hand, gender equality needs to be not only a discourse, but also should be implemented in real life. The second group considers that patriarchal culture and the interpretation of the texts on the roles, the responsibilities, and the relationships between men and women are still questionable.

Gender and Islamic discourse in Indonesia cannot be separated from two points. First, Islam is considered to have an appeal, especially in examining the themes about the development of contemporary thinking related to issues of human rights, pluralism, disability, and gender. Secondly, Islam motivates people not only to criticize the social problems due to science and technology development but also to take a significant role in finding solutions.

However, these issues have not been embodied in the entire Muslim community in Indonesia. This fact may be due to two main factors. First, gender issues have not been well understood by religious leaders, such as kiai (religious leader) and ustädh (religious teacher); Secondly, people are not well-concerned with the discourse that is "difficult to digest". The discourse of gender vis-a-vis Islam is just discussed in limited circles, such as students, lecturers, and enthusiasts of Islamic studies contemporary, even though these activities still get challenges from various parties in Indonesia. ${ }^{1}$

The data about the gender gap that affects gender discrimination are as follows: First, the women's movement in education sector in Indonesia has been initiated by Raden Ajeng Kartini, but education for

\footnotetext{
${ }^{1}$ However, discrimination against women has been reported in some Muslim-majority countries although constitutions among Muslim-majority countries differ. By using women's rights indicators and exploiting cross-country variation, Moamen Goudaa and Niklas Potrafkeb find found that discrimination against women is more pronounced in countries where Islam is the source of legislation. Constitutions have changed in only four Muslim-majority countries since 1980. Moamen Goudaa and Niklas Potrafkeb, "Gender Equality in Muslim-Majority Countries," Economic Systems, 40:4 (2016), p. 683-698.
} 
women still has problems; ${ }^{2}$ Second, Indonesia fails to achieve the target of mother's mortality rate of MDGs of 102 / 100.000 births. Based on the Indonesian Demographic Health Survey (2012), mother's mortality rate in Indonesia was still at 390/100,000 births, and this figure is still high compared to other ASEAN countries up until now; ${ }^{3}$ Third, the total number of female workers in Indonesia increases every year. In the social services sector, the number of women working almost equal to the number of male workers. That situation needs serious government's attention to the rights of women workers to avoid discrimination in the workplace; ${ }^{4}$ Fourth, the role of women in the political field as public decision makers can be seen in the smaller number of female members of the House of Representatives compared with male members. ${ }^{5}$ There is still a gap between men and women in structural positions based on statistical data reaching only $20.09 \% ; 6$ fifth, according to data in 2016 the rate of violence against women is still high. ${ }^{7}$ Sixth, according to the Council of Foreign

2 Gloria Safira Taylor, https://www.cnnindonesia.com/gaya-hidup/20170308130607277-198669/perempuan-indonesia-masih-tertinggal-dalam-pendidikan/. Accessed on 5 March 2017.

${ }^{3}$ Sali Susiana, Kajian Singkat Terhadap Isu Aktual Dan Strategis Aborsi Dan Hak Kesehatan Reproduksi Perempuan, Pusat Penelitian Badan Keahlian DPR RI www.pengkajian.dpr.go.id ISSN 2088-2351 Kesejahteraan Sosial Vol. VIII, No. 06/II/P3DI/Maret/2016. Accessed 10 August 2017.

${ }^{4}$ http://independen.id/read/data/429/jumlah-tenaga-kerja-perempuan-di-indonesia/. Accessed on 16 July 2017.

5 According to Hetifah, the legislative election in 2004 representation of women was 11 percent, then in the 2009 elections was 18 percent, and in 2014, the percentage was 17 percent. The number of women who occupy the Jokowi-JK Cabinet is only 8 people (23\%), Riza Harahap, http://www.antaranews.com/berita/625140/dprketerwakilan-perempuan-di-parlemen-belum-maksimal. Accessed on 7 April 2017. See also Sarah Shair Rosen-field, The alternative incumbency effect: electing women legislators in Indonesia, Electoral Studies, Vol. 31 (2012), 576-587. Rosen-field mentions that between 1999 and 2009 the election of female legislators in Indonesia increased more than doubled. Although this substantial increase can only be triggered by certain parties who want to increase the number of women candidates. Many parties place women at the top of the list of legislative or executive candidates. Newcomer women are greatly benefited by the offer of this position so they can compete with incumbents or old players openly.

6 "Perempuan dan Kebijakan Publik," Jurnal Perempuan, 92, Vol. 22 No 1 (February 2016), p. 4.

${ }^{7}$ In the community domain, the highest violence rate was sexual violence with 2,270 cases $(74 \%)$, physical violence 490 cases $(16 \%)$, other violence below $10 \%$ including 
Relations, Indonesia is one of the ten countries in the world with the highest number of girl sent to early marriage. The figure is estimated that one in five girls in Indonesia married before 18 years old. ${ }^{8}$ The data are consistent with the increasing number of married age dispensation applications. Although the marriage age is regulated in legislation, but the 8,488 cases of dispensation in 2016 should be of concern. There are 8,488 underage marriages certified by the state. Early marriage studies show a negative impact, especially for women. ${ }^{9}$ Trafficking cases of female workers are still continuing. ${ }^{10}$ In addition, Indonesia has the highest divorce rate in Asia Pacific region. ${ }^{11}$

psychological abuse 83 cases (3\%), migrant workers 90 cases (3\%); and trafficking 139 cases $(4 \%)$. Among the sexual violence, rape was the most striking data of violence with 1,036 cases $(46 \%)$, followed by obscenity 838 cases $(37 \%)$. In the domains of domestic violence, the most extreme cases were physical violence with 4,281 cases $(42 \%)$, and it is followed by sexual violence cases: 3,495 (34\%), psychic: 1,451 cases (14\%) and economy: 978 cases (10\%). https://www.komnasperempuan.go.id/wpcontent/uploads/2017/04/CATAHU-2017-Komnas-Perempuan.pdf. Accessed on 20 July 2017.

8 Dewi Candraningrum, "Pernikahan Anak: Status Anak Perempuan?," Jurnal Perempuan, 88, Vol. 21, No. 1 (February 2016), p. 4.

9 https://www.komnasperempuan.go.id/wp-content/uploads/2017/04/CATAHU2017- Komnas- Perempuan.pdf. Accessed on 23 July 2017. This is in line with the research of Yvette Efevbera et al., which shows that marriage of girls affects the health and well-being of their children, especially in sub-Saharan Africa. The data used are 37,558 mother-child pairs identified through 16 sub-national and sub-national surveys across sub-Saharan Africa conducted between 2010 and 2014 by UNICEF's Multiple Indicator Clusters Survey program. See Yvette Efevbera, Jacqueline Bhabha J.D., Paul E. Farmer, and M.D.Günther Fink, "Girl child marriage as a Risk Factor for Early Childhood Development and Stunting," Social Science \& Medicine, Vol. 185 (July 2017), pp. 91-101.

10 All provinces (34 provinces) in Indonesia are both the origin and destination of trafficking. The government estimates that about 1.9 million of the 4.5 million Indonesians working abroad-most of them women-have no documents or have stayed over the residence limit. This situation increases their vulnerability to trafficking. https://en.usembassy.gov/id/laporan-tahunan-perdagangan-orang-2017/. Acccessed on 12 September 2017. In addition, women victims of trafficking will be vulnerable to sexual violence and mental violence resulting in mental disorders Post-Traumatic Stress Disorder (PTSD), depression, anxiety, panic disorder, suicidal ideation, Stockholm syndrome, and drug abuse. In detail, this review can be found in M.Schouler-Ocak, "Women Mental Health and Trafficking," European Psychiatry, Volume 41, Supplement (April 2017), p. 59.

11 Puji Astutik, https://www.jawaban.com/read/article/id/2017/07/24/91/170724142549/ angka_perceraian_indonesia_tertinggi_di_asia_pasifik masa_depan_anakanak_indonesia_dipertaruhkan. Accessed on 24 November 2017. 
The data mentioned above cannot be separated from the people's mindset about women's issues, gender, and religion. The interpretation of the holy texts of the Qur'an and the understanding of Hadith as well as the gender biased Islamic law also support the phenomenon of the gender gap..$^{12}$ Issues of women in interpretation that have an impact on Islamic law such as the position of women as the second sex, polygamy, underage marriage, unregistered marriage, women's reproductive rights, division of public domestic role, women's leadership, and so on. This discriminatory view cannot be separated from the patriarchal culture.

This paper uses the approach of Islamic law sociology to criticize the complexity of women's empowerment problems and gender equality based on mosques in three subcultures in East Java: Mataraman, Tapal Kuda, and Arek'an. Women and mosques have been viewed as two different entities. The mosque is a sacred place and masculine-faced, while women have no ritualistic and even religious social roles in the mosque. These three subcultures represent the typologies of East Java society, especially the views of religious leaders about mosque-based women empowerment.

\section{Muslim Women under Patriarchal Cultural Dominance in East Java}

The strong dominance of patriarchal culture in the society of East Java may slow down the realization of equal, just, harmonious, and prosperous society. Patriarchal culture is a very old cultural style, spread all over the world. ${ }^{13}$ Patriarchal culture becomes the main root

12 The concept of gender and its relationship to law (including Islamic Law) has fluctuated time to time and has been applied in different contexts. It may refer to a distinct set of legal rules and responsibilities governing men and women. The use of the term 'gender' often signals that the topic extends beyond biological differences between men and women and includes the legal significance of gender roles, gender norms, and common understandings of masculinity and femininity. Gender and the law has been tied to sexuality and personal identity, also covering laws relating to sexual orientation and gender identity, as well as legal responses to gender performances, such as appearance, speech, and dress. Martha Chamallas, "Gender and the Law," International Encyclopedia of the Social \& Behavioral Sciences, $2^{\text {nd }}$ edition, Volume 9 , p. 729.

13 The division of sexual labor in the household and gender ideology has been widely discussed by experts. One of them is Yasemin Dildar. In his research in Turkey, Dildar found that patriarchal norms and religiosity negatively affected the participation of women in the world of work. Yasemin Dildar, Patriarchal Norms, "Religion, and 
of the gender discrimination, values, norms, and behavior, spreading across the aspects of human life. Patriarchal culture breeds gender discrimination, injustice and even conflict and violence. The manifestations of gender discrimination are as follows: ${ }^{14}$

First, gender stereotypes in East Java appear in various cultural expressions both in the narrative of languages as well as on symbols that contain gender discrimination to women. For example, in Javanese speech "Wong wadon iku konco wingking (women are men's sub ordinate), swargo nunut neroko kathut (women will follow their husbands, either to heaven or to hell), bojo lanang iku pangeran kathon (The husbands are the reflection of God), wong lanang ombo jangkahe (men's step are further than women's)." 15 In Madurese language, for example "Reng binik padeh ben ben padheringan" (women's main duty is to receive and manage the salary of men, such as the storage of rice), "Reng binik pagghun burub ka dapor" (a woman finally goes to the kitchen). That such stereotype forms a negative image of women and it is crystallized in the form of values, norms, and customs. The roots of this stereotype are stronger when it is justified by a gender-biased interpretation of the sacred texts. ${ }^{16}$

Female Labor Supply: Evidence from Turkey," World Development, Volume 76 (December 2015), pp. 40-61.

${ }^{14}$ Mansour Fakih, Gender dan Transformasi Sosial (Yogyakarta: Pustaka Pelajar, 1997), pp. $12-23$.

${ }^{15}$ Kitab Clokantara mentions: Tiga Ikang abener lakunya ring loka; / / iwirnya, ikang iwah, ikang udwad, ikang janmasri, yen katelu,wilut gatinya,yadin pweka nang istri bana satya budbinya, dadi ikang tunjung tumuwuh ring cela (Three things that are not true on earth are rivers, creeps, and women. The three of them walk around. If there is a straight woman there will be a tunjung flower growing on a rock.) Wuwusekang wus ing ngelmil kaprawolu wanudyo lan priyo/ Ing kabisan myang kuwate/ tuwin wiwekanipun (It is said that when women have finished studying, they are only one eighth of men in terms of intelligence, strength, and wisdom.) Women are labeled with the terms: masak (good at cooking), macak (clever in dressing), manak (able to giving birth). According to Ronggowarsito, there are at least three female characters which are considered by men when choosing a wife: wedi (wretched, not denied) gemi (not extravagant), gemati (loving). Nurwanta, http:// forumkeadilan.com/kritik-ideologi/kritik-ideologi-wanita-makna-dan-filosofidalam-masyarakat-jawa/. Accessed on 5 November 2017.

16 Some of the hadiths are textually used as a theological foundation to support the stereotypes.For example, from Maisaroh al-Asyja'i from Abi Hazim from Abu Hurairah RA, Rasulullah SAW said: "Behave you against women because in fact it is created from the ribs and the most crooked part of the rib is upper. When you straighten it the bone will break and when you leave it, the condition will remain crooked then behave against the women!". Abu Abdillah al-Bukhari, Shabih al-Bukbariy (Beirut: Dar Ibn al-Kathir al-Yamamah, 1987), p. 3. 
Second, subordination. The placement of asymmetrical women with men is based on gender stereotypes. The culture of East Java society still assumes that the position of women as second-class people followed by unharmonious relation and sexist dichotomy roles, but many women consider it as natural. This subordination increasingly exists when collaborating with the gender biased interpretation in sacred texts. For example, the rights of women in inheritance, witnesses, aqiqah (the Islamic tradition of the sacrifice of an animal on the occasion of a child's birth), leadership, livelihood, unregistered marriage and polygamy, and male-female relationships in a family ${ }^{17}$

Third, the marginalization. The process of marginalization of women in East Java is still found such as in the workplace. East Java has a large number of female labors, but legal protection for them has not been effective in solving employment problems. The proportion of female migrant workers from East Java is still high while many of them do not have sufficient knowledge and information about the type of work, salary, and work situation. Therefore, they often become the victims of violence. Also, the division of labor of men and women in the public sector, especially in factories and informal sectors, is followed by the determination of different wages. ${ }^{18}$ Marginalization towards women is due to the interpretation of gender-biased texts. ${ }^{19}$

Fourth, multiple forms of workloads are still experienced by women in East Java. For instance, the gender-based treatment, maleto-female relations, and reproductive-gender role distribution for women. The shape and number of domestic-reproductive roles is

17 The inheritance verse about the division of men and women with the composition of 2: 1 is an-Nisa: 11. It was reported by Muhammad bin al-'Ala ' i, reported from Zaid bin Hubbab, from Ibn Thawus from his father from Ibn Abbas r.a. from Prophet Muhammad SAW, he said: "Give the heirs to the rightful ones, after that, give the rest to the more important of the relatives of the men." An-Nawawi, Shabih Muslim bi Syarh an-Nawawi, Vol. 11 (Beirut: Dar al-Fikr, 1972), p. 52.

${ }^{18}$ Female migrant workers are vulnerable to economic problems, family harmony, and development of their children. Therefore, they need a guidance on family management. The problems experienced by female migrant workers and their families are quite complex, such as her family inability to manage the salary, the harmony of families (infidelity and divorce), and less coaching for their children's growth. http://dp3ak.jatimprov.go.id/index.php/berita/item/89-sosialisasi-dan-advokaksi-kebijakan-perlindungan-perlindungan-tenaga-kerja-perempuan-di-jawa-timur-tahun-2014. Accessed on 2 November 2017.

19 For example, the interpretation of the public-domestic role, mahram, livelihood, inheritance also preserves marginalization of women. 
much greater so that women accept more workloads than men. Women's workloads are much heavier when they also work in the public sector.

Fifth, the rate of violence against women in East Java is still very high, ${ }^{20}$ especially violence in domestic sphere. ${ }^{21}$ The dominance of patriarchy may affect violence due to stereotype, subordination, and marginalization. The majority of violence cases against women are justified by the patriarchal culture and the gender-biased understanding of sacred texts.

The views of East Java people on women's empowerment and gender equality in Islam are as follow:

First, the conservative view. There is an ambiguity in understanding sex differences as natural evidence and gender concepts as social construction. The concept of gender equality is still textual vis-a-vis the universal principles of Islam. Patriarchal cultural nuances are still strongly maintained. In general, their views on women's rights are based on classical fiqh (Islamic Law) arguments. The dominance of patriarchal culture in Muslim societies in East Java legitimizes the gender-biased understanding of religion at all levels of society;

Second, the moderate view. The concept of gender equality is established through the excavation of Islamic values as the religion of rabmah li al-'alamin. Gender is interpreted in the context of social problems that rise to gaps and discrimination, and the dominant group of unfair treatment is women. On this basis, moderate groups separate the concept of sex with the concept of gender as social construction. The criticism of the standardization of the stereotyped role is based on the concept of public-domestic and productive-reproductive

20 Yohana Lambise stressed that the number of violence cases against women in Indonesia reached tens millions of cases. women suffering from violence in all forms amounted to 24 million. the number of violence of women and children in East Java in 2015 reached 672 cases. While in the year 2016, slightly decreased about 600 cases. The number of violence according to the Social Service in East Java did not decrease drastically, but decreased slightly. M. Ardiansyah, https://www.merdeka.com/peristiwa/jumlah-perempuan-korban-kekerasan-di-jatim-masih-tinggi.html, Accessed on 2 September 2017.

${ }^{21}$ In 2015 East Java is ranked second in Indonesia in a complaint of domestic violence cases (KDRT). Citing Police Bareskrim data, cases of domestic violence (KDRT) reached 1,069 complaints in 2015. This number occupies the second position after North Sumatra with 1107 cases. Christyaningsih, http://m.republika.co.id/berita/nasional/daerah/16/09/23/odye6k284-kekerasan-terhadap-anak-dan-perempuan-dijatim-tinggi. Accessed on 14 October 2017. 
dichotomies that are seen as disadvantageous to both men and women. The moderate thought is based on the concept of the welfare of Muslims and Islam is a solution to the problem of gender inequality, but the implementation of gender equality should adapt to culture.

Third, the progressive view. The interpretation of the holy Qur'an and the hadith remains a problem. Some verses of the Qur'an textually indicate gender bias and some hadiths such as misogynist hadiths are still in question. The approach of interpretation and the product of figh in medieval era were gender-biased, and cannot solve the problem of gender inequality in the present days. This progressive view only exists in Muslim societies that already have gender sensitivity and genderresponsive understanding about religious texts. The theological arguments use contemporary fiqh with an interdisciplinary approach. ${ }^{22}$

East Java Muslim community, in understanding women and gender equality, is associated with fiqh, starting from the interpretation of texts. To understand the dominance of patriarchy and gender biased-religious understanding in Muslim societies in East Java, there are three typologies of East Java's subcultures: Mataraman, Tapal Kuda, and Arek'an. $^{23}$ The three typologies of the East Java community are associated with their views on women and gender equality as follows.

First, the sub-culture of the Mataraman community is located in the eastern part of East Java from the north coast to the south coast, near Central Java Province. The language and dialect are closer to the

\footnotetext{
22 Shahrur examines the issue of women through figh perspective, in which women's problems in Islam cannot be solved without the Islamic concept of an outright woman sourced from the limits of God's law and done by Muslims themselves. A number of errors identified by Shahrur conducted by the reviewers on women in particular is related to methodology, for example; Firstly, there is no separation between the verses that address the theme of one woman with other women. Similarly, in discussing the hadiths about women; Second, what the Prophet has produced about women's rights is deemed to be final, whereas women's problems continue to grow. Due to this methodological error, Shahrur offers the idea that the liberation of women in Islam has been initiated by the Prophet, but it has not ended; Third, the methodological error in understanding as the verse that contains the theme of women raises a negative view of women. Muhammad Shahrur, Nabwa Ushu Jadidah li al-Figh al-Islami, Fiqh alMar'ab (Syiria, Damascus: al-Ahali li al-Tiba'ah wa al-Nasr, 2000).

23 A culturalist from Jember University, Ayu Sutarto (2004) divides East Java into ten tlatah or cultural areas. There are four big tlatab: Mataraman, Arek, Madura Island, and Pandalungan while small tlatah consists of Java Panoragan, Osing, Tengger, Madura Bawean, Madura Kangean, and Samin (Sedulur Sikep). Tlatah distinguishes the characteristics of people in East Java.
} 
language of the Mataraman kingdom tradition. Their characteristics are the use of more subtle words, the attention to courtesy, and the application of the noble values of Javanese culture. The view of Mataraman sub-culture is asymmetrical status and relationships between men and women. Men are superior and powerful in socio-political, economic and sexual roles. Norms, values, local wisdom are based on patriarchal culture to create jargon and cultural symbols which are seen as truth from generation to generation. Patriarchal culture is also found in the procession of Javanese traditional marriage with some meaningful symbols of men. The religious view of women and gender equality is only a supplement to argumentation after cultural criticism. The Muslim community of Mataraman subculture is more likely to be in a position between moderate-conservative group.

Second, the sub-culture of Tapal Kuda, located in the eastern part of East Java, is geographically composed of Madura Island and Pendalungan people the so-called Madurese in East Java. In general, they use Madurese language as their mother tongue. The character of the community tends to be paternalistic, where the figure of the religious figure (kiai) becomes a role model as an informal decision maker. Tapal $K u d a$ 's view of women and gender equality is based on religious understanding. Religious figures become the source of truth that shapes their mindset about women and men collaborating with patriarchal culture. Religious religion and religious practice become the dominant argument. The Tapal Kuda subculture of the Muslim community is more likely to be in a position between conservativemoderate groups.

Third, the sub-culture of Arek'an is geographically located in the central part of East Java province from Surabaya to South coast of Malang Regency. The term Arek'an is derived from the title for children and youth with the term 'Arek'. the Characteristics are openminded, rational, and easy to adapt to new situation. The Arek'an community's cultural mindset about women and gender equality is in harmony with their inclusive, egalitarian, rational, heterogenic character. The Muslim society's view of women in this culture is a collaboration between religious views and cultural settings, in a symmetrical position so that the concepts of women and gender equality of religious perspectives through the process of dialogue are both, so that gender equality is readily accepted. The sub-culture of the 
Muslim community of Arek'an is more likely to represent moderateprogressive groups.

The debates of religious leaders on women's empowerment and gender equality are still continuing. The argument used cannot be separated from the interpretation of the Qur'an and hadith, the views of the 'ulama (religious leaders), and the sub-cultural settings of the East Java community i.e. Mataraman, Tapal Kuda, and Arek'an. The debates contribute to the complexity of the problems on gender discrimination. This phenomenon inhibits the empowerment of women in various lines of Muslim society in East Java.

\section{Mosque-based Women Empowerment in East Java}

The religious leader's perception on social and religious roles of mosques is an ongoing debate. Up until now, these places for worship is considered a sacred and holy places, the house of God, the area for the compulsory worship, making mosques not to respond to Muslims' problem, and it contradicts to the roles of mosques at the Prophet's era. When a shifting role of most of the mosques occurs from their historical notes, from a place of social change of the society to the place of merely performing rituals (e.g. five times of prayers), it is a role stunt of the mosques. ${ }^{24}$ The mosque-based program of community empowerment is still a charity and sporadic activity. These religious places are always considered male's areas. Consequently, women's empowerment is hard to develop. In general, women's activities at the mosques are giving a charity, attending female's religious cycle, preparing the logistics of particular events of the holy days of Islam under the control of patriarchal domination of the mosque board (takmir). This non-strategic empowerment model is incapable of making changes and solutions to the complex problems of Muslim women in East Java.

${ }^{24}$ Narrowing the existence and the function of mosques can be in form of an interrelation between the mosques and their members, or the members and the mosques vice versa. For instance, the decreasing number of Muslims who perform five times prayers at the mosques. The numbers are not equivalent to the number of Muslims living around the mosques. Also, there is a gap of the content of religious messages delivered at the mosques with the reality of Muslims' conducts outside the mosques. Amril Mansur, "Masjid dan Transformasi Sosial Etis: Upaya Pemberdayaan Masjid dalam Kehidupan Sosial," Jurnal Innovation, Vol. IX, No. 1 (January-June 2010), pp. 145-146. 
The existing Muslim women's organization is an autonomous body at sub ordinate position to the organization led by men, for example, Muslimat NU, Fatayat NU as the branch bodies of NU at each level. Similarly, Aisyiyah and Nasyiatul Aisyiah are the autonomous women's wing of Muhammadiyah. Wanita Persis and Muslimah LDII are in the same position as well. These women's organizations do not focus on mosques as their movement base. It further strengthens patriarchal domination at the mosques which is similar to the culture of a kingdom, establishing a sexist overview.

When the religious leaders in East Java perceive the mosques in a conservative and exclusive way, it will affect to the women's participation which are decreasing. In addition, the ritual activities at the mosques are dominated by men under the control of religious leaders. As a result, women are marginal group of the mosque and its role. It can be explained as follows:

First, there is a general perception that the prayer of a man is more importantly performed at the mosque, and a woman's prayer is at home. Also, it is obligatory for men to conduct the Friday prayer at the mosque, making this religious place is a habitat for men. The perception of women's participation in praying at the mosque refers to the gender role division assigning men as solely breadwinners and domestic roles for women with the theological and cultural reasons, physical differences of both sexes as well. Men as the breadwinners are their permanent duty, which is equivalent to the reproduction role of women and it is considered a permanent as well for them. Both roles breadwinners and reproduction- are treated differently generating discrimination based on the cultural identity of the society regarding the utility access of the mosque. ${ }^{25}$

To the second, it is not acommon picture for a woman to participate as the member of the mosque board culturally. It is due to a gender streotype describing a man to be stronger, more capable to lead compared to a woman who is weaker and less competent in managing an organization. This different stereotype is used as the base for

25 The burden (taklif) of men and women is adapted to the context of their physical and psychic differences. The different burdens are not due to gender differences, but there are external factors (socio-cultural constructs) relating to norms and to the common good. M. Said Ramdhan Al-Buthi, Al Mar'ah Baina Tughyani An Niz̧hami AlGharbi wa Lithaifi At Thasyri' Ar Rabbani, Translated by Darsim Ermaya Imam Fajruddin, Perempuan antara Kedzaliman Sistem Barat dan Keadilan Islam (Solo: Era Intermedia, 2002). 
assigning social roles for men and women, which is also a base for job distribustion at the mosque. Furthermore, at the same time, it becomes an instrument for recognition and social neglation, causing social roles of the mosques tend to be a segregation and women even lose their roles. Bakan Deaux and Kahn state:

"Gender differences in interpersonal values, styles, or goals are responsible. Women are assumed to be more communal, more status-neutralizing, and more oriented relationship with their partners. Men in contract, are assumed to be more agented, more status-assertive, and more concerned with performing the task and maximizing material rewards". ${ }^{26}$

Third, women "are not" religious leaders who lead the rituals. The board of the mosque are on the hand of men as a consequence from being religious leaders. In east Java, some cases reveal that the head of mosques board have lower academic and leadership competences than female leaders. However, the core problem is on the notion assigning men as the absolute leader of the members of the mosque, not the women. Women have their handicap of biological reproductive role, which is natural and prohibiting them to perform particular rituals inside or outside the mosques. Although their social mosque-based activities are not related to ritual activities, East Java people still consider reproduction role of women is a theological handicap for them. Hence, the presence of women at the mosques is considered not urgent. Ridha mentions that male-biological difference-perceiving to be more prestigious than female is caused by a natural difference of human beings, ${ }^{27}$ and her notion differs from what is proposed by $\mathrm{Ja}^{\prime} \mathrm{far}^{28}$.

${ }^{26}$ Brenda Major, Gender, Justice, and The Psychology of Entitlement in Sex and Gender, edited
by Phillip Shaver and Clyde Hendrick (London: Sage Publications, 1987), p. 126 .
${ }^{27}$ The advantages of men over women is a natural because Allah overwhelms men due
to his strong physical form, his mind is sharper so as to be given the responsibility to
be the family leader, and the surplus of men as the basis for the giving of men's special
roles. Women's specific reproductive roles are natural, including educating children,
and managing their husbands' households. Women can be leaders in certain contexts
and within the domestic sphere. Muhammad Rasyid Ridha, Al Nida' Li al Jins al Lathif,
Translated by Afif Muhammad, Panggilan Islam Terbadap Perempuan (Bandung: Pustaka,
1986 )
${ }^{28}$ In the perspective of classical fiqh, women are considered to have some weaknesses
compared to men including Nuqshan al fitri in form of mind, causing women is less
capable intellectually than men. Nuqsan al nau' as follow: Irady which can destroy basic 
Fourth, religious and social decision making according to the Muslim community in East Java is considered sufficiently represented by men. Men are considered to have a good understanding of the necessities of women. Therefore, the process of decision making does not need the participation of women. The female members of mosques are the cultural adherents of the decision made by mosque board, and it is obligatory for them to practice the decision. Meanwhile, women issues that can only be understood by women themselves are neglected. Consequently, their contribution to the common good is not maximum. This perception positions men as supra-ordinate and women as the sub ordinate. ${ }^{29}$

Some of religiou leaders in East Java have a proggressive and inclusive perception about the function of the mosques not only as a place for basic rituals performance,but it is also a base for community development. This progressive notion is based on: First, there is no theological reason forbidding women to make the mosque prosperous; 30 Second, they use fiqh with female perspective or approach and consider the common good (advantages) to gain the benefit and to avoid the disadvantages (mudärat). ${ }^{31}$ According to both

insidental character in particular conditions such as menstruation, pregnancy, and breastfeeding. This reason is mostly used as an argument to make women to not deserve to be a leader. Muhammad Anas Qosim Ja'far, Al Huquq al Siyasiyah li al Mar'ah fi al Islam wa al Fikr wa al Tasyri, trans. Mujtaba Hamdi, Mengembalikan Hak-hak Politik Perempuan Sebuab Perspektif Islam (Jakarta: Azan, 2001).

29 The intellectual reform (fikrah al-ta'dhim) notion for women to build constructive mentality emphasizing the importance of women's presence at public sphere.The historical passages note, women are alsways left behind from men because men are able to organize themselves, but women are not, they are in the disorder condition. Shalah Qazan, Nahwa Fikrin Nisaiyyin Harakiyyin Munaz̧am, Translated by Khazin Abu Fakih, Membangun Gerakan Menuju Pembebasan Perempuan (Surakarta: Era Intermedia, 2001).

30 The Prophet says: "You shall not hinder the women who will enter the places of worship where God is worshiped." Another saying of Prophet Mentions: "Do not forbid women to go to the mosques of Allah". Muhamad Bin Abu Abdillah Al Ju'fiy, Shabih Bukhori, Vol. 1 (Beirut: Dar Ibnu Katsir, 1987), p. 52.

31 To guarantee gender equality and equity, there are two effors can be taken by applying ushulal-fiqh approach, namel; First, upholding the goodness and perfection of life through the common good (mashlabah) approach; Second, to protect against discrimination and injustice against women in life through shari'ah. In principle, maslahah is taking the advantage and refusing disadvantages in order to maintain the 
arguments, in fact, women's access to mosques is unlimited. Their participation in board mosque activities will bring back the social fuction of the mosques as their function in time of prophet, spreading the message of Islam, which is rahmah li-álamin, democratic, egalitarian, and just. This inclusive viewpoint about the mosque expands the role of mosque and maintain the interrelation between the mosque and its members to change. ${ }^{32}$ Therefore, the mosque is understood as a medium to build a vertical relation between human and God (Allah), a medium to develop science and skill, a medium to alleviate the poverty, ignorance, dependence, and marginalization, then, the mosques has assign its actual function. ${ }^{33}$

The shifting paradigm as a consequence of mosque-based women empowerment can be seen as follows:

First, the society argues that women's participation in all aspects of life is inevitable. Their access to mosques not only as the congregation of the praying, which is followed by marginalization of their social roles, but they also play a role as an actor of da'wab bi al-lisān and bi alhăl (oral and action preaching). Muslims need female figures who are inspiring and can do a social change especially for female members like the role of women in preaching at the early age of Islam. Women issues which are developing up to now demand their active participation in providing solutions, and the mosques are the place to do the problem-solving.

Second, desicion making is no longer dominated by men because the issues proposed by the program and activities of mosques are broader and more complex. Some of religious leaders open an access for women and their strategic roles, in a team with men or they separately run a specific programs for them. Women empowerment

goals of shara'. Abu Hamid al-Ghazali, Al-Mustashfa' fi 'Tlm al-Ushül, Vol.1 (Beirut: Dar Al Kutub al-Ilmiyah, 1983), p. 286.

32 Kuntowijoyo expressed his concern about a general view describing the mosque which is considered an obstacle to the development. Kuntowijoyo, Muslim Tanpa Masjid (Bandung: Mizan, 2001), p. 127. It is necessary to have a subtantive integration that brings together Islamic science and social science. Muslims need mosques to express their religious feelings and the mosques need its members to make them prosperous or to make them alive, so a simbiosis mutualistic can be manifested. A. Bachrun Rifa'i and Moch Fakhruroji, Manajemen Masjid Mengoptimalkan Fungsi Sosial Ekonomi Masjid (Bandung: Benang Merah Press, 2005), p. 97.

33 Ahmad Sarwono, Masjid Jantung Masyarakat (Yogyakarta: Izzan Pustaka, 2003), p. 185. 
obliges their presence at the mosque physically to join in a meeting, to discuss empowerment program, to propose ideas in order they can take a role in making a decision. Step by step, it can move women'sub ordination to the direction of egality, marginalization to mainstream. This notion is in line with the principle of gender equality and equity that is proposed by Ali Asghar ${ }^{34}$ and Qasim Amin. ${ }^{35}$

Third, women's entrance to the organization structure of mosque board is a necessity. When women empowerment program is integrated into women mosque-based participation, women might gain their socio-religious roles significantly. Though female role model appears to drive the society and to have creative and innovative ideas to build harmony among Muslims, which is prosperous and just. Women's participation in social role of mosque is similar to the women's condition at the Prophet's era. ${ }^{36}$ The wider access of women

34 The concept of gender equity for women is emphasized through women's individual statuses not as men'subordinate. Islam recognizes the dignity of both men and women equally, posing equal rights in social, economic, politic, desicion making, freedom, and similar responsibility. Asghar Ali Engineer, The Rights of Women in Islam, translated by Farid Wajidi and Cici Farkha Assegaf, Hak-hak Perempuan dalam Islam (Yogyakarta: Yayasan Banteng Budaya, 1994).

35 Rights and obligations for men and women stipulating at the holy book are the same. The gap appears due to particular streotype and patriarchal culture which is oppressive. Hence, women's access and participation to education are very low. Women need freedom to express and to make their own decision independently. By having qualified education level, women can gain their equal position to men in their life. Qasim Amin, The New Woman: A Document in the Early Debate of Egyptian Feminism, Translated by Syaiful Alam, Sejarah Penindasan Perempuan: Menggugat Islam Laki-laki, Menggugat Perempuan Baru (Yogyakarta: IRCISoD, 2003).

36 A health Muslim community is signed by an equity, democracy, openness, and justice because the Quran and hadith promote equity. The examples of the life of the Prophet with His family and his surrounding people, including women from Anshar who were actively played a role among the society is a role model for other women.Aisyah and Ummu Salamah involved in public desicion making process. The Prophet gave a big opportunity to women to ask about women issues and his wife as the source of knowledge especially about women. Khadijah had an important role in providing moral support, economic supply, and smart ideas in succeeding the prophecy missions. That is the reason why did the Prophet could not forget Khadijah's deed throughout his life. When He passed away, Aisyah played a role as a mufty at Abu Bakar era. Hafsah gave considerations in making political decision making for her father Umar bin al Khattab when Umar was the khalifah, Al Syifa' was a supervisor at Madinah market at the era of Utsman bin Affan. Jawad A. Haifaa, The Right of Women in Islam (An Authentic Approach), translated by Moh. Salik, Perlawanan Wanita Sebuah Pendekatan Otentik Religius (Malang: Cendekia Paramulya, 2002). 
can bridge the gap between the mosque and its members. Women who are in the structure of mosque board focus on education, preaching, entrepreneurship, health, and environment. For instance, managing kindergarten school (PAUD), School for Quran education (TPQ), religious cycle (majlis taklim), training for processing of agricultural products and mentoring of micro business unit to marketing of entrepreneurial products, maternal health services, toddlers, youth and the elderly, managing waste banks, and productive use of environmental movements.

The changing mindset of the society, especially among religious leaders, about women empowerment at the mosque pass through gradual social process. The changing mindset about gender concept as a social construction needs space and time as well as intensive social interaction, positioning mosque as the right cultural medium to facilitate this changing. ${ }^{37}$ With regard to the religious leadersand the mosque board's perception about mosque-based women empowerment, there are different features of their tendency toward that issue among three different typology of Muslim community as follows:

First, Religious leaders from Mataraman subculture argue that culture and its value, norm and local wisdom tend to be gender bias and it influences their perception on women empowerment at the mosque. A number of mosques with progressive typology provide a wider access to women. Women's participation at the mosque tends to be a social awareness on religion. Their roles in making social change in different aspects are potential enough. For instance, managing kindergarten school (PAUD), School for Quran education (TPQ), preaching, entrepreneurship, environment, and the mediators among the stakeholders. Mataraman subculture is easy to accept the presence of women at the mosque but a psychological handicap appears from

\footnotetext{
37 According to social construction theory, society is a human product and human is the product of their society. Both- human and their society- describe an inherent dialectical character from a social phenomenon. Berger combines several perspectives from sociology theories considering some other aspects to be theoretical construction which is able to answer plural, dynamic, and complex problems. The fundamental dialectical process from the society consists of three momentums, namely: externalization, objectification, and internalization. The three dialectical processes are strengthen by a legitimization which has cognitive and normative dimensions, mentioning by Berger as a social fact. Peter L. Berger, Langit Suci Agama Sebagai Realitas Sosial, trans., Hartono (Jakarta: LP3ES, 1994), pp. 4-5.
} 
women themselves. As a result, the open access for women appears from themselves. Therefore, the access has not utilized maximally by women. The feeling of "reluctant" to interact socially with the male members of mosque is the handicap for them to express their creative ideas. Not all women have utilized the discussion forums at the mosques as a cultural medium for community development. As an instance, women still depend on men to make a decision and to people they consider more senior than them although an equal access with men is already there. ${ }^{38}$ One the one hand, the group of women prefers specific activity for women, which is segregated from men. On the other hand, men's domination at the organization structure of mosque board habitually position women as men's subordinate, but they enjoy the position without any critics because they are worried to against the established cultural values and norms. In general, there is a resistance towards women empowerment in socio-religious activities regardless theological arguments with fiqh perspective like linking the religious overview to women, but it tends to be influenced by the value and the norm of of the cultural setting Mataraman community itself.

Second, religious leaders and the mosque board (takmir) at Tapal Kuda society with its paternalistic character also affects this group's point of view on women empowerment at mosque. Their understanding about mosque is generally conservative. Also, they treat women and gender equity with religious arguments and religious practices of their religious leaders. A number of mosque provides an access to take part in socio-religious roles, but the paternalistic and patriarchal nuance is still very strong. People separate between women's role at mosque and their public roles especially as economic actors, merchants at the markets, or informal labors. Tapal Kuda Women's role from low level group are very significant, but they disappear when they are public mosque-based roles. Some of

38 The habits and views of women who tend to position themselves as subordinates make them sometimes less independent in making decisions. The subordinate position of women results in different male and female leadership patterns. An-Chih Wang et al.'s paper shows that gender differences between men and women are harmful to women because they will not be maximised in completing their work as women's leadership roles tend to be more hesitant in making decisions than male. See An-Chih Wang, Jack Ting-Ju Chiang, Chou-Yu Tsai, Tzu-Ting Lin, Bor-Shiuan Cheng, "Gender Makes the Difference: The Moderating Role of Leader Gender on the Relationship between Leadership Styles and Subordinate Performance," Organizational Behavior and Human Decision Processes, Volume 122, Issue 2 (November 2013), pp. 101-113. 
progressive mosques have their structure of mosque board (takmir), but without any scheduled activities. Therefore, the majority of women go to the mosque only for praying and teaching the Quran for children (TPQ) or participate passively in certain religious activities which are very limited their roles. If they get involved in the activities, they play unimportant roles. For example, they distribute the meals for women's religious cycle (majlis taklim) or Islamic holy days, to recite the Quran, to perform as a master of ceremony, and all the roles should be in accordance with the fatwa (a legal pronouncement) of the head of mosque board or local religious leaders. The mosque based community development in this community is slower than those in Mataraman and Arekan groups.

Third, the Arek'an subculture with its opened, heterogeneous, rational, and dialogical characters influence its religious leaders' and the mosque board's perception on mosque-based women empowerment. In general, the mosques in the area of Arekan people are progressive and inclusive mosques. It results in the accessibility to women and the access facilitates them to participate in social and religious roles. Some women are on the list of the mosque board (takmir) although they just included in particular divisions. Men and women work as a team in social and religious activities for a changing. Women in this community have a critical ability as an expression for an openness and well established dialogical construction in order their work performance are effective and maximum. For instance, the development of entrepreneurship and micro credit business, farming production, product marketing, kinder garden school management, women religious cycle (majlis taklim), health services for women, babies, and elderly people, utilization of land to be more productive land, etc. They can play a role as more effective communicators among stakeholders than women from Mataraman and Tapal Kuda groups. If they find internal or external obstacles, they easily find the solutions for the obstacles.

\section{The complexity and challenges of mosque-based women's role in East Java}

Women's presence in participatory and mosque-based participatory empowerment activities is unlikely to penetrate the roles of religious ritual leaders, but at least public awareness of the importance of revitalizing the role and function of mosques in the field of social and 
religious activities is growing, especially which has been accessible to women who initially felt they did not have a concern with the mosque, turned into a part of the mosque itself. Women not only support the existence of mosque-based empowerment but they also as the engine and buffer for the sustainability of the religious and social program of the mosque.

The role of women in the mosque has shifted the public understanding of the image of women in society, but it still has some challenges. The challenge is a result of gender discrimination which occurs at mosque and in daily life of a community and it occurs in various forms, especially in social strata and various subcultures. Discrimination and gender inequality in its various forms is reinforced by socio-cultural legitimacy, gender-biased religious interpretation, and unresponsive gender legislation and policies. ${ }^{39}$ This phenomenon is also experienced by Muslim communities in other Muslim countries. ${ }^{40}$

The complex problem of discrimination includes cultural aspect, structural aspect, and religious interpretation as follows:

First, cultural aspects that cause gender inequality are patriarchal culture, gender ideology, gender stereotypes, gender norms, and gender labor division. In this context, patriarchal culture is the most profound root, and then it is considered local wisdom which has to be preserved, defended, and treated as sacred. This culture in the East Java community both in the subculture of Mataraman and subculture of Tapal Kuda have the roots of Keraton (Kingdom) tradition, carrying the practice of feudalism into society. It represents the highest class of

\footnotetext{
39 Another research shows that social order needs the voluntary compliance of the majority of the population. Such consent requires normative justification. The rational foundation of the rule of law and the democratic state rests on the presumption of the equality of every citizen. Male domination of females nevertheless remains universal because it is legitimized by the shared assumption that patriarchy reflects the will of God or is dictated by nature. J.C. Smith and David N. Weisstub, "The Unconscious, Myth, and the Rule of Law: Reflections on the Persistence of Gender Inequality," International Journal of Law and Psychiatry (2016), p. 1.

${ }^{40}$ For example, Malaysia has always walked a fine line between protecting the rights of Malay women and acknowledging the role that Islam plays in the daily lives of its citizens. Yet many of the obstacles facing Malaysian society disproportionately affect women. There are two different and extreme sorts of discourses: one that strictly adheres to the classical Islamic tradition and the other rejects the mere notion of polygamy as they do not believe that Islam promotes any injustice and mistreatment towards them. Aurangzaib Alamgir, "Islam and Women's Rights: Discourses in Malaysia," Procedia - Social and Behavioral Sciences, Volume 114 (2014), pp. 872-876.
} 
society based on ownership and asset mastery supported by 'blue blood' tradition; then it is used as legitimacy for the practice of maleto-female relation. The description men and women are different in tradition, women with their reproductive roles represent the proletariat, while men with their production roles represent the bourgeoisie. Men's superior stigma, the controller of women's social and sexual life, makes them the winner over women. This sexist power relationship has an impact on conflict and the gender-based violence which are not considered as problems by the society. This strong patriarchal culture causes the majority of women to lose their critical power over their problems. When women lose their critical power, it will form inferiority and a low self-image for women. Hence, this is the beginning of the internal psychological barriers of women themselves. Also, patriarchal culture is mostly associated with the myths of women's degradation. Moreover, this myth used as an argument of discrimination against women in various forms. Furthermore, women internally still experience many psychological barriers caused by strong external challenges, as if they are facing a gigantic wall that is difficult to tear down. Women are essentially not weak, but they are weakened by a particular structure and culture. These internal barriers have an impact on the difficulties of women in exploiting access that has been fully opened. This phenomenon convinces the public to argue that the weakness of women is a permanent character that crystallizes in the form of negative stigma or stereotype. As a result, this negative stigma causes a lack of women's self-confidence in actualizing themselves, especially at the mosque environment, where men's dominance is powerful. ${ }^{41}$ As a result, this negative stigma causes a lack of women's self-confidence in actualizing themselves, especially at the mosque environment, where men's dominance is powerful.

Second, a gender-biased religious understanding makes the realization of gender equality in Muslim societies is slower than in other non-Muslim societies. On the one side, The power relation in superordinate power structures, in which men who occupy mainstream areas such as religious leaders who dominate sacred mosques, makes

${ }^{41}$ In classical Islamic Jurisprudence, women is perceived to have some weaknesses, namely: nuqshan al fitri (mind), making them are less intellectual than men and nuqsan al nau'- irady which can influence their incidental basic characters such as menstruation, pregnancy, and breast feeding. This argument is used to weaken women's potential as if their weaknesses are permanent. Haifaa, The Right of Women in Islam. 
women subordinate and marginal. Even religious decision makers have not been fully able to facilitate the change of gender bias towards gender responsiveness. On the other side, there is still a patriarchal culture with political configuration that affects gender discrimination, while the Muslim community itself is not yet established and has not been able to provide supra-structural protection to women. ${ }^{42}$ Narrative text of the interpretation of women is not easy to obtain, the absence of interpretation of religious texts with equality and gender justice not because it does not exist, but rather because many interpreters promoting the religious doctrines tend to be gender biased. ${ }^{43}$ This phenomenon affects popular religious messages, which are discriminatory against women. The strong influence of religious figures that are still biased is the main obstacle for women, especially their mosque-based activities. Religion seems to be 'male', when it falls into the hands of exclusive religious figures in collaboration with patriarchal and paternalistic cultures. In fact, Islam is very respectful of women's rights, and it keeps women's dignity as human beings as equal as men. Unfortunately, the reality of Muslim life has not been as ideal as Islamic values.

Third, the state takes some efforts to integrate the policy of mainstreaming gender in national development, down to the regional level in various ministries to the district level. The government implements this gender mainstreaming with superstructure, infrastructure, gender responsive budgets, and instruments of progress measurement. This policy periodically has been evaluated through gender-based development indicators, which formulated down to the

\footnotetext{
42 The Madinah charter is the basic foundation of civil society which has constitution components and basic principles to develop the society, such as humanity, justice, democracy, equity, including the effort against any forms of discrimination in Islam like gender discrimination. The Prophet protected women from any acts of violence and humanity violation. Also, He improved the moral standard among the Arabs. Margaret Smith, Rabi-a; the Mystic and Her Fellow-saints in Islam (London: Cambridge University Press, 2010), trans. Jamilah Baraja, Rabi'ab: Pergulatan Spiritual Perempuan (Surabaya: Risalah Gusti, 1997).

43 The total number of Hadith on gender equity is greater than those which are Mysoginy, but sociologically the usage of the misogynic hadith are more popular than those which have equity messages. Consequently, the hadith that aimed by the Prophet to improve women's dignity are not covered perfectly. Badriyah Fayumi, "Makhluk yang Paling Mendapat Perhatian Nabi: Perempuan dalam Hadits,” Ali Munhanif (ed.), Mutiara Terpendam Perempuan dalam Literatur Islam Klasik (Jakarta: Gramedia Pustaka Utama, 2002).
} 
local level, but not yet fully able to break the links of gender discrimination in the community.

The gender development index at the ASEAN level records Indonesia in reaching 92.74 above the average, 91.03 nationally and in East Java Province reached 91.77 .44 In the last five years, the trend of the gender development index has increased. But in reality, there are still practices of gender discrimination in society with the same repetition, although the practices are different in forms. Such as cases of domestic violence in East Java that became the second highest cumulative after DKI Jakarta ${ }^{45}$, the number of divorces in East Java ranks first ${ }^{46}$, while violence against children, especially sexual violence, ranks first nationally ${ }^{47}$, as bad as trafficking and so on. There are still obstacles to the implementation of gender mainstreaming. In the opinion of the officers, the policy considered as an unimportant workload, there are officers who committed halfheartedly in guarding the policy of mainstreaming gender, and there are still cultural barriers to agencies or organizations that harass women through speech, and gender insensitivity. Usually women tend to be silent, although they are able to resist. Culturally women are aware that the public is the area of men. Thus, the structural approach in breaking the chain of gender discrimination is still influenced by the growing patriarchal culture in society and the views of the religious leaders who helped to strengthen it.

${ }^{44}$ Kementerian PP-PA, Pembangunan Manusia Berbasis Gender, https://www.kemenpppa.go.id/lib/uploads/list/4f9aa-buku-pmbg-2016-min.pdf. accessed on 18 November 2017.

45 Jakarta province stands as the highest rate with 2,552 cases, followed by East Java as many as 1635 cases, West Java 1.377 cases, and Central Java 1.123 cases. Yurike Budiman, http://www.tribunnews.com/nasional/2017/03/08/jakarta-duduki-rangking-tertinggi-kasus-kekerasan-terhadap-perempuan. accessed on 24 November 2017.

46 Social minister Khofifah Indar Parawansa states that, East Java province, based on the data of local religious office of East Java, in 2016, registers 303.773 marriages, 58.232 divorce cases by women, 27.894 cases by men, and 3.087 marriage dispensation. Sulha Handayani, http://www.netralnews.com/news/kesra/read/105358/angka.perceraian.di.jatim.tinggi. accessed on 24 November 2017.

47 The Ministry of social affairs records five provinces which have the figure of high rate of children sexual abuse cases with East Java stood as the highest contributor of the total numbers of the five provinces. http://www.republika.co.id/berita/nasional/umum/16/09/27/oe5urz365-jawa-timur-tertinggi-kasus-kekerasan-seksual. accessed on 12 September 2017. 
Solutions that can be offered in overcoming these obstacles are as follows: first, socialization of gender equality through social discussions and interactions in women's religious empowerment activities such as in mosques, so that women are no longer seen as second class people. ${ }^{48}$ Second, open access for women to hold strategic roles, in order to communicate creative and innovative ideas in the developing the empowerment, so that decision making always involves women. ${ }^{4}$ Third, campaigning for women cadres who have achievement, potential and intelligence. So they are better known to the public, in hope of improving women's empowerment quantitatively and qualitatively for strategic roles on a religious basis. ${ }^{50}$ Fourth, strengthening the capacity of women to have a strong identity and initiative in developing progressive thinking for the advancement of social-religious role,

48 The gender mainstreaming has played its role in reducing gender inequality in Egypt. There is a need to improve the full commitment and implementation. Also, gender mainstreaming should be accompanied by feminist and human rights approaches. To make a success for the mainstreaming, including men, culture and a consensus among women should be considered. See Farah Gamal Shash and Carie L. Forden, "Gender Equality in a Time of Change: Gender Mainstreaming after Egypt's Arab Spring," Women's Studies International Forum, Volume 56 (May-June 2016), p. 74-82.

49 Although there is an evidence of insignificant differences in leadership skill between men and women in society, women are still absent in the leadership position and senior management. Furthermore, only a few number of studies on leadership in social relation indicating gender influence on leadership performance and success. Katie R. Place and Jennifer Vardeman-Winter found that most of researches on leadership and gender concern with less motivated women's leadership, the factors behind the less motivated leadership, leadership style and women's preference, their leadership roles, women's management as well. They provide recommendations to improve women's presence in leadership roles, especially in providing a roadmap for future research opportunities. These include considerations for methodological approaches, leadership approaches and role studies, types of leadership, cultural change, and education. Katie R. Place and Jennifer Vardeman-Winter, "Where are the Women? An Examination of Research on Women and Leadership in Public Relations," Public Relations Review, available online 11 November 2017, https://www.sciencedirect.com/ science/article/pii/S0363811117302904.

50 Amanda Bullough, K. Galen Kroeck, William Newburry, Sumit K. Kundu, and Kevin B. Lowe, "Women's Political Leadership Participation around the World: An Institutional Analysis," The Leadership Quarterly, Volume 23, Issue 3 (June 2012), pp. 398-411. They maintain that currently women throughout the world have growing access to the public. In indicates that women's promotion to reach strategic position is necessary. 
especially the development based on mosque. ${ }^{51}$ Fifth, preparing women-friendly policies and managements, equipped with infrastructure facilities to facilitate women in accessing and participating in social and religious activities maximally and effectively.

\section{Conclusion}

The discussion can be summarized as follows: First, the society's view of women and gender equality according to East Java society is constructed by cultural setting and religious interpretation. In the three typologies of East Java society, there are diversity of views: Mataraman society is more influenced by culture, while religion becomes only a supporting factor; Tapal Kuda society is dominated by the views of religious leaders who become their patrons and strengthened by cultural factors that tend to be patriarchy; While the people of Arek'an are constructed from open and rational dialogue between religion and culture, so it is easy to accept gender equality and justice. Second, the role of women in the mosque only takes on the social-religious field with its diversity of expression. This is influenced by their view on women and gender equality, conservative, moderate or progressive, as well as two typologies of conservative-exclusive or progressiveinclusive forms. Third, the view of the East Java Muslim community about the role of women in the mosque from a progressive view still encounters some obstacles.

The role of women in the mosque has not improved, based on indicators that include women and men equality in access, participation, control, and benefits. Empowerment of women in the management of board of mosque (takmir) remains in subordinate position. The strategic role of community empowerment activities or programs is still dominated by men, so women tend to be marginalized. The participation of women in some mosques is still like

51 In general, in 74 countries over the world, the effect of education for women on their work performance is positive. Education is the main motor driving women's work performance and empowerment throughout the world. A development study shows the power of the effect of education, but it varies from one country to another. Theoretically, the mechanism of human capital theory and modernization theory explain the relation between education and job. Carlijn Bussemakers, Karsvan Oosterhout, Gerbert Kraaykamp, and Niels Spierings, "Women's Worldwide Education-employment Connection: A Multilevel Analysis of the Moderating Impact of Economic, Political, and Cultural Contexts," World Development, Volume 99 (November 2017), pp. 28-41. 
'jemput bola' (passive action) on the initiative of men (invited by men), not yet fully departed from the initiative of women independently. However, the role of women-based on the mosque is slowly able to break the chain of patriarchal culture. It also creates a breakthrough of Muslim society structures that are still paternalistic-patriarchal through a dialogical process, social interaction, and productive activities that empower and potentially change the mindset.]

\section{References}

\section{Books and Articles}

Al Ju'fiy, Muhamad Bin Abu Abdillah. Shahih Bukhori. Vol. 1. Beirut: Dar Ibnu Katsir, 1987.

al-Bukhari, Abu Abdillah. Shabih al-Bukhariy. Beirut: Dar Ibn al-Kathir al- Yamamah, 1987.

Al-Buthi, M. Said Ramdhan. Al Mar'ah Baina Tughyani An Niz̧hami AlGharbi wa Lithaifi At Thasyri' Ar Rabbani. translated by Darsim Ermaya Imam Fajruddin. Perempuan antara Kedzaliman Sistem Barat dan Keadilan Islam. Solo: Era Intermedia, 2002.

al-Ghazali, Abu Hamid. Al-Mustashfa' fi 'Ilmu al-Ushul. Vol. 1. Beirut: Dar Al Kutub al-Ilmiyah, 1983.

Al-Nawawi, Shabih Muslim bi Syarh an-Nawawi. Vol. 11. Beirut: Dar alFikr, 1972.

Amin, Qasim. The New Woman: A Document in the Early Debate of Egyptian Feminism. translated by Syaiful Alam. Sejarab Penindasan Perempuan: Menggugat Islam Laki-laki, Menggugat Perempuan Baru. Yogyakarta: IRCISoD, 2003.

Engineer, Asghar Ali. The Rights of Women in Islam. Translated by Farid Wajidi and Cici Farkha Assegaf. Hak-hak Perempuan dalam Islam. Yogyakarta: Yayasan Banteng Budaya, 1994.

Fakih, Mansour. Gender dan Transformasi Sosial. Yogyakarta: Pustaka Pelajar, 1997.

Fayumi, Badriyah, et.al. "Makhluk yang Paling Mendapat Perhatian Nabi: Perempuan dalam Hadits" Ali Munhanif (ed.). Mutiara Terpendam Perempuan dalam Literatur Islam Klasik. Jakarta: Gramedia Pustaka Utama, 2002. 
Goudaa, Moamen and Niklas Potrafkeb. "Gender Equality in MuslimMajority Countries,” Economic Systems, 2016.

Ja'far, Muhammad Anas Qosim. Al Huquq al Siyasiyah li al Mar'ah fi al Islam wa al Fiker wa al Tasyri'." Translated by Mujtaba Hamdi. Mengembalikan Hak-bak Politik Perempuan Sebuah Perspektif Islam. Jakarta: Azan, 2001.

Ollenerburger, Jane C, Helen A. Moore. Sociology of Women. Trans. Budi Sucahyono. Sosiologi Wanita. Jakarta: Rineka Cipta, 1996.

Jawad A, Haifaa. The Right of Women In Islam (An Autenthic Approach). Translated by Moh Salik. Perlawanan Wanita Sebuah Pendekatan Otentik Religius. Malang: Cendekia Paramulya, 2002.

Kuntowijoyo. Muslim Tanpa Masjid. Bandung: Mizan, 2007.

Berger, Peter L. Langit Suci Agama Sebagai Realitas Sosial. Translated by Hartono. Jakarta: LP3ES, 1994.

Qazan, Shalah. Nabwa Fikrin Nisaiyyin Harakiyyin Munazham. Translated by Khazin Abu Fakih. Membangun Gerakan Menuju Pembebasan Perempuan. Surakarta: Era Intermedia, 2001.

Ridha, Muhammad Rasyid. Al Nida' li al-Jins al-Lathif. Translated by Afif Muhammad. Panggilan Islam Terbadap Perempuan. Bandung: Pustaka, 1986.

Rifa'i, A. Bachrun and Moch Fakhruroji. Manajemen Masjid Mengoptimalkan Fungsi Sosial Ekonomi Masjid. Bandung: Benang Merah Press, 2005.

Sarwono, Ahmad. Masjid Jantung Masyarakat. Yogyakarta: Izzan Pustaka, 2003.

Shahrur, Muhammad. Nahwa Ushul Jadidah li al-Figh al-Islami, Fiqh alMar'ah. Syiria, Damaskus: Al-Ahali li al-Tiba'ah wa al-Nasr, 2000.

Smith, Margaret. Rabi-a; The Mystic and Her Fellow-Saint in Islam. London: Cambridge University Press. Translated by Jamilah Baraja, Rabiab: Pergulatan Spiritual Perempuan. Surabaya: Risalah Gusti, 1997.

Ziyadah, Asma' Muhammad. Daurah al-Mar'ah al-Siyasah. Translated by Kathur Suhardi, Peran Politik Wanita dalam Sejarah Islam. Jakarta: Pustaka al-Kautsar, 2001. 
Amanda Bullough, K. Galen Kroeck, William Newburry, Sumit K. Kundu, and Kevin B. Lowe, "Women's political leadership participation around the world: An institutional analysis." The Leadership Quarterly, Volume 23, Issue 3 (June 2012).

Amril Mansur, "Masjid dan Transformasi Sosial Etis: Upaya Pemberdayaan Masjid dalam Kehidupan Sosial." Jurnal Innovation, Vol. IX, No. 1 (Januari-Juni 2010).

An-Chih Wang, Jack Ting-Ju Chiang, Chou-Yu Tsai, Tzu-Ting Lin, Bor-Shiuan Cheng. "Gender Makes the Difference: The Moderating Role of Leader Gender on the Relationship between Leadership Styles and Subordinate Performance.” Organizational Behavior and Human Decision Processes. Volume 122, Issue 2 (November 2013).

Aurangzaib Alamgir, “Islam and Women's Rights: Discourses in Malaysia." Procedia-Social and Behavioral Sciences. Volume 114, 2014.

Brenda, Major. Gender, Justice, and the Psychology of Entitlement in Sex and Gender. Edited by Phillip Shaver and Clyde Hendrick. London: Sage Publications, 1987.

Karsvan, Carlijn Bussemakers, Oosterhout Gerbert Kraaykamp, and Niels Spierings. "Women's Worldwide Education-employment Connection: A Multilevel Analysis of the Moderating Impact of Economic, Political, and Cultural Contexts." World Development, Volume 99 (November 2017).

Dewi Candraningrum. "Pernikahan Anak: Status Anak Perempuan?." Jurnal Perempuan. 88, Vol. 21, No. 1 (February 2016).

Shash, Farah Gamal and Carie L. Forden, "Gender equality in a time of Change: Gender Mainstreaming after Egypt's Arab Spring." Women's Studies International Forum. Volume 56 (May-June 2016).

Smith, J.C. and David N. Weisstub. "The Unconscious, Myth, and the Rule of Law: Reflections on the Persistence of Gender Inequality." International Journal of Law and Psychiatry (2016).

Place, Katie R. and JenniferVardeman-Winter. "Where are the women? An examination of research on women and leadership in public relations." Public Relations Review, Available online 11 November 
2017, https://www.sciencedirect.com/science/article/pii/S0363811117302904.

M. Schouler-Ocak, "Women Mental Health and Trafficking." European Psychiatry, Volume 41, Supplement (April 2017).

Chamallas, Martha. "Gender and the Law." International Encyclopedia of the Social \& Behavioral Sciences. $2^{\text {nd }}$ edition, Volume 9.

"Perempuan dan Kebijakan Publik." Jumal Perempuan. 92, Vol. 22, No 1 (February 2016).

Yasemin Dildar, "Patriarchal Norms, Religion, and Female Labor Supply: Evidence from Turkey." World Development, Volume 76 (December 2015).

Efevbera, Yvette Jacqueline Bhabha J.D., Paul E. Farmer, and M.D. Günther Fink. "Girl Child Marriage as a Risk Factor for Early Childhood Development and Stunting." Social Science \& Medicine, Vol. 185 (July 2017).

\section{Intenet Sources}

Christyaningsih. http://m.republika.co.id/berita/nasional/daerah/16/09/23/odye6k284-kekerasan-terhadap-anak-dan-perempuandi-jatim-tinggi. Accessed on 14 October 2017.

Taylor, Gloria Safira. https://www.cnnindonesia.com/gaya-hidup/20170308130607-277-198669/perempuan-indonesia-masih-tertinggal-dalam-pendidikan/. Accessed on 5 March 2017.

Handayani. http://www.netralnews.com/news/kesra/read/105358/angka.perceraian.di.jatim.tinggi. Accessed on 24 November 2017.

http://dp3ak.jatimprov.go.id/index.php/berita/item/89-sosialisasidan-advokaksi-kebijakan-perlindungan-perlindungan-tenaga-kerja-perempuan-di-jawa-timur-tahun-2014. Accessed on 2 November 2017.

http://independen.id/read/data/429/jumlah-tenaga-kerja-perempuandi-indonesia/. Accessed on 16 July 2017.

http://www.republika.co.id/berita/nasional/umum/16/09/27/oe5urz 365-jawa-timur-tertinggi-kasus-kekerasan-seksual. Accessed on 12 September 2017. 
Mufidah Ch.

https://id.usembassy.gov/id/laporan-tahunan-perdagangan-orang2017/. Accessed on 12 September 2017.

https://www.goodnewsfromindonesia.id/xhr/render/article/sosialbudaya/jatuh-hati-pada-wayang-para-bule-ini-pilih-jadi-dalang/1484735220/3. Accessed on 4 November 2017

https://www.komnasperempuan.go.id/wp-content/uploads/2017/04/CATAHU-2017-Komnas-Perempuan.pdf. Accessed on 20 July 2017.

Kementerian PP \& PA, Pembangunan Manusia Berbasis Gender, https://www.kemenpppa.go.id/lib/uploads/list/4f9aa-buku-pmbg2016-min.pdf. Accessed on 18 November 2017.

Ardiansyah, M. https://www.merdeka.com/peristiwa/jumlah-perempuan-korban-kekerasan-di-jatim-masih-tinggi.html. Accessed on 2 September 2017.

Nurwanta. http://forumkeadilan.com/kritik-ideologi/kritik-ideologiwanita-makna-dan-filosofi-dalam-masyarakat-jawa/. Accessed on 5 November 2017.

Astutik, Puji. https://www.jawaban.com/read/article/id/2017/07/24/91/170724142549/ angka_perceraian_indonesia_tertinggi_di_asia_pasifikmasa_depan_anak-anak_indonesia_dipertaruhkan. Accessed on 24 November 2017.

Harahap, Riza. http://www.antaranews.com/berita/625140/dpr-keterwakilan-perempuan-di-parlemen-belum-maksimal. Accessed on 7 April 2017.

Susiana, Sali. Kajian Singkat Terhadap Isu Aktual Dan Strategis Aborsi Dan Hak. Kesehatan Reproduksi Perempuan, Pusat Penelitian Badan Keahlian DPR RI www.pengkajian.dpr.go.id ISSN 2088-2351 Kesejahteraan Sosial Vol. VIII, No. 06/II/P3DI/Maret/2016. Accessed on 10 August 2017.

Yurike Budiman, http://www.tribunnews.com/nasional/2017/03/08/jakarta-duduki-rangking-tertinggi-kasus-kekerasan-terhadapperempuan. Accessed on 24 November 2017. 